\title{
Effect of INM Practices on the Leaves Parameters of Terminalia tomentosa Food Plant of Antheraea mylitta Drury
}

\author{
Soma Karmakar ${ }^{1}$, A.K. Srivastava ${ }^{1}$, T. Pandiaraj ${ }^{2}$, Jyostna Tirkey ${ }^{3}$
}

10.18805/ag.D-5441

\begin{abstract}
Background: Terminalia tomentosa is a primary food plant of Antheraea mylitta Drury a polyphagous insect of Saturniidae family which is exploited commercially for the production of silk. Good quality of silk production depend on the nutrient of leaf. So, to optimize the nutrient of leaf integrated nutrient management practices has been used to increase soil fertility and to supply plant nutrient at an optimum.

Methods: In order to evaluate the effect of INM practices on the leaves parameters of Terminalia tomentosa food plant of Antheraea mylitta Drury. An experiment based on randomised complete block design with 21 treatments and three replication was conducted at Central Tasar Research and Training Institute, Nagri, Ranchi in the year 2019-20.

Result: Results revealed that the application of INM treatments are significant on various leaf parameters. Highest single leaf length and breadth mean was observed in $\mathrm{T}_{19}(23.29 \mathrm{~cm} ; 11.96 \mathrm{~cm})$ was applied with $75 \%$ RDF through fertilizer+25\% through vermicompost+ Azotobacter + PSB, weight of single leaf was found to be highest in $\mathrm{T}_{13}(5.19 \mathrm{~g})$. The number of leaf was recorded highest in $\mathrm{T}_{19}(1892)$. The fresh leave yield ranged from $1617.317-5208.224 \mathrm{~g}$ with average mean of $4085.72 \mathrm{~g}, \mathrm{~T}_{19}(5032.1 \mathrm{~g})$ recorded the highest fresh leaf yield. The dry matter content was found highest in $\mathrm{T}_{19}(340.56 \mathrm{~g})$. The moisture content was recorded higher in $\mathrm{T}_{4}(71 \%)$ followed by $T_{15}(69 \%)$.
\end{abstract}

Key words: Azotobacter, Antheraea mylitta, Moisture, Terminalia tomentosa, Vermicompost.

\section{INTRODUCTION}

Antheraea mylitta the wild silkworm which is commercially exploited for the production of Vanya silk (Bambhaniya et al., 2017 ) is a polyphagous insect and feeds on mainly three primary and dozens of secondary host plant (Suryanarayana et al., 2005). Tussar silk in sanskrit is known as "Kosa Silk" (Nakpathom et al., 2009; Pilanee Vaithanomsat et al., 2008) and is valued for its rich texture and natural deep gold colour (Vigneswaran et al, 2015). The tribes and people of weaker section residing in the hilly areas practices this culture since ancient time (Chakraborty, 2018) for their livelihood. The silkworm's silk gland produces the silk fibre which is a protein mainly consist of fibroin and sericin. The fibroin is coated by a double filament gum called sericin. Sericin helps in the formation of silk cocoon because it acts as a binder which maintains the structural integrity (Patel and Modasiya, 2011, Takeda, 2009). The silk obtained post-cocoon processing depend upon the nutritional contents of leaves (Sinha et al., 2002), indicating the importance of leaf quality in the success of Tasar crops (Sahey et al., 2001). The foliage quality depend upon judicious management of inputs such as water, micro and macro-nutrients (Sahay and Kapila, 1993). Sufficient amount of balanced nutrients are made available by using organic resources like green manure, vermicomposts, biofertilizer and vermibed/vermiwash as biopesticides having some antibiotic property and which helps in overcoming nutritional depletion (Zambare et al., 2008 and Subsashri, 2004). Fertilization with organic manure enhance the SOC, increase the concentration of nutrients like $\mathrm{N}, \mathrm{P}, \mathrm{K}$ and improves the yield and also influence the
1Department of Botany, Ranchi University, Ranchi-834 008, Jharkhand, India.

${ }^{2}$ Narendra Deva University of Agricultural Technology, Azamgarh276 207, Uttar Pradesh, India

${ }^{3}$ Central Muga Eri Research and Training Institute, Jorhat-785 700, Assam, India.

Corresponding Author: Soma Karmakar, Department of Botany, Ranchi University, Ranchi-834 008, Jharkhand, India.

Email: msmarten436@gmail.com

How to cite this article: Karmakar, S., Srivastava, A.K., Pandiaraj, T., Tirkey, J. (2021). Effect of INM Practices on the Leaves Parameters of Terminalia tomentosa Food Plant of Antheraea mylitta Drury. Agricultural Science Digest. DOI: 10.18805/ag.D-5441.

Submitted: 06-07-2021 Accepted: 09-10-2021 Online: 19-11-2021

microbial biodiversity (Pratibha and Shachi, 2016) and also increases the total microbial community than those treated with chemical fertilizers (Islam et al., 2009). SOM provide $90 \%$ of plant available N, $80 \%$ of plant available P and $50 \%$ of plant available $S$ as well as micronutrients (Duxbury et al., 1989). Nitrogen, Phosphorus and Potassium are considered primary nutrient as required in large quantities by plant than the rest of the nutrients (Hodges, 1995). Integrated nutrient management along with chemical fertilizers, organic manures and biofertilizers are found to maintain soil fertility and also reduce the cost of cultivation for sustaining increased productivity, an integrated manner is suitable for each farming situation in its ecological, social 
and economical conditions for a longer time. The present investigation was carried out to study the effect of INM practices on the leaf parameters.

\section{MATERIALS AND METHODS}

The present study was carried out in the field of Central Tasar Research and Training Institute, Nagri, Ranchi in the year 2019-20 to determine the influence of inorganic, organic and biofertilizer on Leaf parameters of host plant of Tasar Silkworm (Antheraea mylitta Drury). Twenty different combination with three replication were laid out in randomized complete block design (Table 1).

\section{Sample collection and processing}

Leaf sample were collected from each treatments for further analysis.

\section{Morphological parameters (Mallapa, 2015) \\ Length and breadth of leaf $(\mathrm{cm})$}

Length and Breadth of leaf were measured from each treatment.

\section{Weight of single leaf $(\mathrm{g})$}

Weight of single leaf from each treatment were recorded.

\section{Number of leaves plant $^{-1}$}

Total number of leaves per treatment were counted.

\section{Leaf yield (g plant ${ }^{-1}$ )}

Leaf yield per plant was recorded on fresh weight basis in grams.

Dry matter production of leaf (g plant $\left.{ }^{-1}\right)$

Leaves of each treatment were collected randomly and were

Table 1: Treatment details.

\begin{tabular}{ll}
\hline Treatments & Treatments detail \\
\hline $\mathrm{T}_{1}$ & Absolute control \\
$\mathrm{T}_{2}$ & Control with recommended dose fertilizer (RDF) \\
$\mathrm{T}_{3}$ & $50 \%$ RDF through fertilizer $+50 \%$ through vermicompost \\
$\mathrm{T}_{4}$ & $75 \%$ RDF through fertilizer $+25 \%$ through vermicompost \\
$\mathrm{T}_{5}$ & $100 \%$ RDF through fertilizer+2\% through vermicompost \\
$\mathrm{T}_{6}$ & $50 \%$ RDF + Azotobacter \\
$\mathrm{T}_{7}$ & $75 \%$ RDF + Azotobacter \\
$\mathrm{T}_{8}$ & $100 \%$ RDF + Azotobacter \\
$\mathrm{T}_{9}$ & $50 \%$ RDF + Phosphorus solubilizing bacteria (PSB) \\
$\mathrm{T}_{10}$ & $75 \%$ RDF + PSB \\
$\mathrm{T}_{11}$ & $100 \%$ RDF + PSB \\
$\mathrm{T}_{12}$ & $\mathrm{~T}_{3}+$ Azotobacter \\
$\mathrm{T}_{13}$ & $\mathrm{~T}_{4}+$ Azotobacter \\
$\mathrm{T}_{14}$ & $\mathrm{~T}_{5}+$ Azotobacter \\
$\mathrm{T}_{15}$ & $\mathrm{~T}_{3}+\mathrm{PSB}$ \\
$\mathrm{T}_{16}$ & $\mathrm{~T}_{4}+\mathrm{PSB}$ \\
$\mathrm{T}_{17}$ & $\mathrm{~T}_{5}+\mathrm{PSB}$ \\
$\mathrm{T}_{18}$ & $\mathrm{~T}_{3}+$ Azotobacter+PSB \\
$\mathrm{T}_{19}$ & $\mathrm{~T}_{4}+$ Azotobacter+PSB \\
$\mathrm{T}_{20}$ & $\mathrm{~T}_{5}+$ Azotobacter+PSB \\
\hline
\end{tabular}

air dried followed by oven drying $60^{\circ} \mathrm{C}$ to a constant weight and expressed in grams.

\section{Physiological parameters \\ Moisture content (\%)}

Fresh leaves were harvested from each treatment and weighed in electronic balance to note the fresh leaf weight. Then, the leaves were oven dried at $70^{\circ} \mathrm{C}$ for 48 hours and the dry weight was recorded and expressed on fresh weight basis (Gravimetric Method). The leaf moisture content was calculated as per the standard of A.O.A.C 1970.

Moisture \% =

$$
\frac{\text { Fresh weight of leaf }- \text { Dry weight of leaf }}{\text { Fresh weight of leaf }} \times 100
$$

\section{Statistical analysis}

Statistical analysis was carried out using ANOVA and SPSS 20.0 and duncan's multiple range test (DMRT) was used to determine significance of the difference between individuals means (Gomez and Gomez,1984).

\section{RESULTS AND DISCUSSION Morphological and yield parameters}

The leaf parameters were found to be significant in different treatment with inorganic, organic and biofertilizer due to slow and steady release of nutrients in addition to supply of important macro and micro-nutrients besides supply of $\mathrm{N}$ and $\mathrm{P}$ by nitrogen fixing bacteria and phosphorus solubilizing bio-inoculants respectively (Khan and Pariari, 2012, Rashmi et al., 2006 and Mallapa et al., 2016). The length and breadth of single leaf increased after the application of different treatment. Highest mean of single leaf length was recorded in $\mathrm{T}_{19}(23.29 \mathrm{~cm})$ was applied with $75 \%$ RDF through fertilizer $+25 \%$ through vermicompost + Azotobacter + PSB. The breadth was recorded highest in $T_{19}(11.96 \mathrm{~cm})$ over the control. Weight of single leaf was recorded highest in $T_{13}$ $(5.19 \mathrm{~g})$ and lowest was recorded in $T_{15}(2.64 \mathrm{~g})$. The highest number of leaves was recorded in $\mathrm{T}_{19}$ (1892) was applied with $75 \%$ RDF through fertilizer $+25 \%$ through vermicompost + Azotobacter+PSB was followed by $\mathrm{T}_{15}$ (1704). Increase in number of leaves per plant, average leaf length, leaf width, plant girth was reported by Chaudhuri et al., 2016. Increase in leaf number per plant was reported by Singh et al., 2012 and Mallapa et al., 2016. Leaf weight indicates the size of photosynthetic system (Ram C. Adhikari). Leaf weight is directly related to the level of $\mathrm{N}$ applied (Puskarnath, 1976 and Taya et al., 1994). The fresh leave yield ranged from 1617.317-5208.224 g with an average mean of $4085.72 \mathrm{~g}$. The highest leaf yield was recorded in $\mathrm{T}_{19}$ was treated with $75 \%$ RDF through fertilizer $+25 \%$ through vermicompost + Azotobacter + PSB. Fresh leaf yield was reported Mallapa et al., 2016, Chakraborty, 2018 and Ram, 2017 and increments in leaf yield in Terminalia tomentosa was also reported by Singhvi, 2014. Increase in leaf yield using biofertilizer and INM was 
Effect of INM Practices on the Leaves Parameters of Terminalia tomentosa Food Plant of Antheraea mylitta Drury

Table 2: Effect of INM practices on leaf quality parameters.

\begin{tabular}{|c|c|c|c|c|c|c|c|c|c|c|}
\hline \multirow{2}{*}{ Treatments } & \multicolumn{2}{|c|}{ Length $(\mathrm{cm})$} & \multicolumn{2}{|c|}{ Breadth $(\mathrm{cm})$} & \multicolumn{2}{|c|}{ Weight (g) } & \multicolumn{2}{|c|}{ No. of leave plant ${ }^{-1}$} & \multicolumn{2}{|c|}{ Leaf yield $\mathrm{g}$ plant ${ }^{-1}$} \\
\hline & Mean & Rank & Mean & Rank & Mean & Rank & Mean & Rank & Mean & Rank \\
\hline $\mathrm{T}_{1}$ & $14.53^{\mathrm{k}}$ & 20 & $6.05^{\prime}$ & 20 & $3.45^{\mathrm{h}}$ & 16 & $816^{\prime}$ & 20 & $1638.08^{k}$ & 20 \\
\hline $\mathrm{T}_{2}$ & $17.39^{j}$ & 19 & $8.42^{h}$ & 13 & $2.98^{i j}$ & 18 & $970^{\mathrm{k}}$ & 19 & $2793.51^{j}$ & 19 \\
\hline $\mathrm{T}_{3}$ & $22.02^{\mathrm{bc}}$ & 4 & $10.15^{c}$ & 3 & $4.47^{c}$ & 5 & $1060^{\mathrm{j}}$ & 17 & $3764.4^{\mathrm{h}}$ & 15 \\
\hline $\mathrm{T}_{4}$ & $21.25^{\mathrm{cd}}$ & 5 & $8.86^{9}$ & 12 & $4.24^{d}$ & 6 & $1006^{k}$ & 18 & $4067.45^{\mathrm{g}}$ & 13 \\
\hline $\mathrm{T}_{5}$ & $19.1^{\operatorname{tgh}}$ & 12 & $7.39^{j}$ & 17 & $3.09^{i}$ & 17 & $1433^{e}$ & 6 & $4285.29^{f}$ & 12 \\
\hline $\mathrm{T}_{6}$ & $19.31^{\mathrm{fg}}$ & 10 & $9.4^{\mathrm{e}}$ & 7 & $3.93^{f}$ & 13 & $1220^{g h}$ & 11 & $3594.2^{\mathrm{h}}$ & 16 \\
\hline $\mathrm{T}_{7}$ & $20.4^{\mathrm{dc}}$ & 7 & $9.3^{\mathrm{e}}$ & 9 & $4.18^{\mathrm{de}}$ & 9 & $1176^{\mathrm{h}}$ & 14 & $3959.92^{g}$ & 14 \\
\hline $\mathrm{T}_{8}$ & $18.37^{\text {hij }}$ & 16 & $9.22^{\mathrm{ef}}$ & 10 & $4.23^{d}$ & 8 & $1101^{i j}$ & 16 & $3193.81^{i}$ & 17 \\
\hline $\mathrm{T}_{9}$ & $19.31^{\mathrm{fg}}$ & 9 & $9.4^{\mathrm{e}}$ & 6 & $3.93^{f}$ & 14 & $1246^{g}$ & 10 & $4796.78^{b c}$ & 5 \\
\hline $\mathrm{T}_{10}$ & $19.52^{\mathrm{ef}}$ & 8 & $9.48^{\mathrm{de}}$ & 5 & $4.49^{c}$ & 4 & $1113^{i}$ & 15 & $4697.37^{c d}$ & 6 \\
\hline $\mathrm{T}_{11}$ & $18.63^{\mathrm{hi}}$ & 13 & $9.37^{e}$ & 8 & $3.98^{e f}$ & 12 & $1315^{f}$ & 9 & $4533.7^{\mathrm{de}}$ & 7 \\
\hline $\mathrm{T}_{12}$ & $21.21^{\mathrm{cd}}$ & 6 & $8.0^{i}$ & 15 & $4.24^{d}$ & 7 & $1488^{d}$ & 4 & $4396.93^{e f}$ & 9 \\
\hline $\mathrm{T}_{13}$ & $22.86^{\mathrm{ab}}$ & 2 & $10.54^{b}$ & 2 & $5.19^{a}$ & 1 & $1346^{f}$ & 8 & $4376.4^{\mathrm{ef}}$ & 10 \\
\hline $\mathrm{T}_{14}$ & $18.46^{\text {hij }}$ & 15 & $8.26^{\mathrm{hi}}$ & 14 & $4.02^{\mathrm{ef}}$ & 11 & $1190^{h}$ & 13 & $3139.1^{i}$ & 18 \\
\hline$T_{15}$ & $18.16^{\text {hij }}$ & 17 & $6.33^{\prime}$ & 19 & $2.64^{k}$ & 20 & $1704^{b}$ & 2 & $4298.56^{f}$ & 11 \\
\hline$T_{16}$ & $18.6^{\mathrm{hi}}$ & 14 & $6.95^{k}$ & 18 & $2.87^{\mathrm{j}}$ & 19 & $1567^{c}$ & 3 & $4397.29^{e f}$ & 8 \\
\hline $\mathrm{T}_{17}$ & $17.79^{\mathrm{ij}}$ & 18 & $7.58^{j}$ & 16 & $3.65^{9}$ & 15 & $1415^{\mathrm{e}}$ & 7 & $4954.75^{\mathrm{ab}}$ & 2 \\
\hline $\mathrm{T}_{18}$ & $19.28^{\mathrm{fg}}$ & 11 & $8.93^{\mathrm{fg}}$ & 11 & $4.15^{\mathrm{de}}$ & 10 & $1204^{\mathrm{gh}}$ & 12 & $4896.6^{\mathrm{ab}}$ & 4 \\
\hline $\mathrm{T}_{19}$ & $23.29^{a}$ & 1 & $11.96^{a}$ & 1 & $4.56^{c}$ & 3 & $1892^{\mathrm{a}}$ & 1 & $5032.1^{\mathrm{a}}$ & 1 \\
\hline $\mathrm{T}_{20}$ & $22.69^{\mathrm{ab}}$ & 3 & $9.79^{d}$ & 4 & $4.75^{b}$ & 2 & $1449^{d e}$ & 5 & $4898.05^{\mathrm{ab}}$ & 3 \\
\hline Mean & 19.608 & & 8.768 & & 3.952 & & 1285.55 & & 4085.72 & \\
\hline S.Em \pm & 0.2783 & & 0.1839 & & 0.085 & & 33.083 & & 110.019 & \\
\hline Range & $14.05-24.11$ & & $5.947-12.184$ & & $2.547-5.33$ & & $807.92-1935.52$ & & $1617.317-5208.224$ & \\
\hline $\mathrm{CD}(95 \%)$ & 0.557 & & 0.3681 & & 0.170 & & 66.198 & & 220.1476 & \\
\hline
\end{tabular}

observed by Nambiar and Abrol, 1992 and Anil Kumar and Johan,1999. Increase in yield is due to improving plant growth and accumulation of high amounts of sugar which play effective role for cell division and increase in total yield of plant (Waleed and Iman, 2017) (Table 2).

The dry matter content of leaf was found highest in $T_{19}$ (340.56 g) which was applied with 75\% RDF through fertilizer $+25 \%$ through vermicompost+ Azotobacter+PSB and was as per with $\mathrm{T}_{20}(333.27 \mathrm{~g})$. Increase in dry matter production was reported by K. Mahantesh Sajan et al., 2002 (Table 3).

\section{Physiological characters}

The moisture content was recorded higher in $\mathrm{T}_{4}(71 \%)$ followed by $T_{15}(69 \%)$ and $T_{6}, T_{10}(67 \%)$. Increase in leaf moisture content was reported by Chowdhury et al., 2009, Sujathamma et al., 2014 and Ram, 2017. The beneficial effect of organic resources result in improvements of growth attributes, leaf yield and quality due to proper decomposition, mineralization of solubilizing effects and availability of sufficient nutrients. This was corroborated with the findings of Das et al.,1990, Sudhakar et al., 2000 and Setua et al., 2007 (Table 4).

Combined application of chemical fertilizer and organic fertilizers mitigate the deficiency of many secondary and micronutrients (Sujathamma et al., 2014) and biofertilizer application improves the growth and yield parameters by enhancing the uptake of nutrient by plants (Borea,1991).
Table 3: Dry matter content ( g plant $^{-1}$ ) of Terminalia tomentosa influenced by INM practices.

\begin{tabular}{lcc}
\hline & \multicolumn{2}{c}{ Dry matter g plant $^{-1}$} \\
\cline { 2 - 3 } Treatments & Mean & Rank \\
\hline $\mathrm{T}_{1}$ & $\mathbf{2 4 . 4 8 ^ { \mathrm { i } }}$ & 20 \\
$\mathrm{~T}_{2}$ & $48.5^{\mathrm{k}}$ & 19 \\
$\mathrm{~T}_{3}$ & $84.8^{\mathrm{hi}}$ & 16 \\
$\mathrm{~T}_{4}$ & $70.42^{\mathrm{j}}$ & 18 \\
$\mathrm{~T}_{5}$ & $128.97^{\mathrm{h}}$ & 12 \\
$\mathrm{~T}_{6}$ & $85.4^{\mathrm{hi}}$ & 15 \\
$\mathrm{~T}_{7}$ & $235.2^{\mathrm{c}}$ & 5 \\
$\mathrm{~T}_{8}$ & $88.08^{\mathrm{hi}}$ & 14 \\
$\mathrm{~T}_{9}$ & $186.9^{\mathrm{f}}$ & 8 \\
$\mathrm{~T}_{10}$ & $55.65^{\mathrm{k}}$ & 18 \\
$\mathrm{~T}_{11}$ & $236.7^{\mathrm{c}}$ & 4 \\
$\mathrm{~T}_{12}$ & $178.56^{\mathrm{g}}$ & 11 \\
$\mathrm{~T}_{13}$ & $255.74^{\mathrm{b}}$ & 3 \\
$\mathrm{~T}_{14}$ & $83.3^{\mathrm{i}}$ & 17 \\
$\mathrm{~T}_{15}$ & $185.74^{\mathrm{f}}$ & 10 \\
$\mathrm{~T}_{16}$ & $94.02^{\mathrm{hi}}$ & 13 \\
$\mathrm{~T}_{17}$ & $226.4^{\mathrm{d}}$ & 6 \\
$\mathrm{~T}_{18}$ & $204.68^{\mathrm{f}}$ & 7 \\
$\mathrm{~T}_{19}$ & $340.56^{\mathrm{a}}$ & 1 \\
$\mathrm{~T}_{20}$ & $333.27^{\mathrm{a}}$ & 2 \\
Mean & 157.368 & \\
$\mathrm{~S} . \mathrm{Em} \pm$ & 11.967 & \\
Range & $23.49-351.54$ & \\
$\mathrm{CD}(95 \%)$ & 23.947 & \\
\hline
\end{tabular}


Table 4: Influence of INM practices on moisture (\%) of Terminalia tomentosa.

\begin{tabular}{|c|c|c|}
\hline \multirow{2}{*}{ Treatments } & \multicolumn{2}{|c|}{ Moisture \% } \\
\hline & Mean & Rank \\
\hline $\mathrm{T}_{1}$ & $60.67^{g}$ & 20 \\
\hline $\mathrm{T}_{2}$ & $61.66^{\mathrm{fg}}$ & 19 \\
\hline $\mathrm{T}_{3}$ & $64.33^{\text {cdef }}$ & 11 \\
\hline $\mathrm{T}_{4}$ & $71^{\mathrm{a}}$ & 1 \\
\hline $\mathrm{T}_{5}$ & $66^{\text {bcde }}$ & 5 \\
\hline $\mathrm{T}_{6}$ & $67^{\text {bcd }}$ & 4 \\
\hline $\mathrm{T}_{7}$ & $63^{\text {efg }}$ & 13 \\
\hline $\mathrm{T}_{8}$ & $64^{\text {cdef }}$ & 8 \\
\hline $\mathrm{T}_{9}$ & $62^{\mathrm{fg}}$ & 16 \\
\hline $\mathrm{T}_{10}$ & $67^{\mathrm{bc}}$ & 3 \\
\hline $\mathrm{T}_{11}$ & $64.33^{\text {cdef }}$ & 7 \\
\hline $\mathrm{T}_{12}$ & $63.33^{\text {efg }}$ & 15 \\
\hline $\mathrm{T}_{13}$ & $64.33^{\text {cdef }}$ & 10 \\
\hline $\mathrm{T}_{14}$ & $63.33^{\text {efg }}$ & 14 \\
\hline $\mathrm{T}_{15}$ & $69^{\mathrm{ab}}$ & 2 \\
\hline $\mathrm{T}_{16}$ & $62^{\mathrm{fg}}$ & 18 \\
\hline$T_{17}$ & $64.33^{\text {cdef }}$ & 9 \\
\hline $\mathrm{T}_{18}$ & $62^{\mathrm{fg}}$ & 17 \\
\hline $\mathrm{T}_{19}$ & $65.33^{\text {cde }}$ & 6 \\
\hline $\mathrm{T}_{20}$ & $63.67^{\text {defg }}$ & 12 \\
\hline Mean & 64.415 & \\
\hline S.Em \pm & 0.3699 & \\
\hline Range & $59.608-73.449$ & \\
\hline CD (95.0\%) & 0.740 & \\
\hline
\end{tabular}

Azotobacter and Azospirillium aid in increased growth due to their nitrogen fixing capacity and also produced growth promoting substances like IAA and GA (Jackson and Brown 1966). PSB was able to solubilise the insoluble form of phosphorus and make it easily available to plants (Sajan et al., 2002).

\section{ConcLusion}

The INM practices was found to effect significantly different parameters of leaf and also increased the leaf yield. The inorganic fertilizer is costly and also has hazardous effect on the environment and health hazard to human. On the other hand biofertilizer are cost-effective and non-toxic. Combined application of organic manure along with inorganic and biofertilizer improves nutrient efficiency, protect nutrient from lose and cause less degradation to soil and environment.

\section{ACKNOWLEDGEMENT}

The authors are highly thankful to the Director of Central Tasar Research and Training Institute for providing the lab facility and the Head of University, Department of Botany, Ranchi University, Ranchi for constant support and guidance.

\section{REFERENCES}

Adhikari, R.C. (2009). Effect of NPK on vegetative growth and yield of desire and Kufri Sindhuri Potato. Nepal Agric. Res. J. 9: $67-75$.
AOAC (1970). Official Methods of Analysis (Ed. Daniel Banes) Published by A.O.A.C., Washington, D.C. Banglore. 105.

Bambhaniya, K.C., Naik, N.M. and Ghetiya, L.V. (2017). Biology of tasar silkworm, Antheraea mylitta Drury under indoor conditions. Trends in Biosciences. 10(1): 126-131.

Borea, J.M (1991). Vesicular-Arbuscular Mycorrhizae as Modifiers of Soil Fertility. In: Advances in Soil Science. Springerveriag, New York. Vol. 15: pp. 2-31.

Chakraborty, B. (2018). Evaluation of the leaf productivity of Terminalia arjuna and its impact on commercial traits of Tropical Tasar Silkworm (Antheraea mylitta Drury) under organic based agro forestry system. Proceedings of ISER $125^{\text {th }}$ International Conference, Malacea, Malaysia. pp: 6-8.

Chakraborty, B. and Kundu, M. (2015). Effect of biofertilizer in combination with organic manures on growth and foliar constituents of Mulberry under Rainfed lateritic soil condition. The International Journal of Engineering and Sciences. 4(3): 16-20.

Chaudhuri, P.S., Paul, T.K., Dey, A., Datta, M., Dey, S.K. (2016). Effects of rubber leaf litter vermicompost on earthworm population and yield of pineapple (Ananas comosus) in West Tripura. India Int. J. Recycle Org. Waste Agricult. 5: 93-103.

Chowdhury, P., Setua, G.C., Ghosh, A., Kar, R., Shivnath, S.K., Maity and Bajpai, A.K. (2009). Organic farming approach for sustainable quality leaf production in mulberry (Morus alba L.) var S-1635 under irrigated condition. Journal of Crop and Weed. 5(1): 38-43.

Das, P.K., Chowdhury, P.C., Ghosh, A., Mallikarjuna, B., Suryanarayana, N. and Sengupta, K. (1990). Effect of green manuring, dry weed and black polythene mulching on soil moisture conservation, growth and yield of mulberry and their economics under rainfed condition. Indian J. Seric. 29: 263-72.

Duxbury, J.M., Smith, M.S., Doran, J.M. (1989). Soil Organic Matter As a Source and a Sink of Plant Nutrients. In Dynamics of Soil Organic Matter in Tropical Ecosystems. University of Hawaii, Honolulu, HI, USA, 2: 33-67.

Gomez, K.A. and Gomez, A.A. (1984). Statistical Procedures for Agricultural Research. John Willey and Sons. New York, USA.

Hodges, S.C. (1995). Soil FertilityBasics. North Carolina State University, Soil Science Extension. 2-75.

Islam, M.R., Trivedi, P., Palaniappan, P., Reddy, M.S., Sa, T. (2009). Evaluating the effect of fertilizer application on soil microbial community structure in rice based cropping system using fatty acid methyl esters (FAME) analysis. World J. Microbial Biotechnol. 25: 1115-1117.

Jackson, K.M. and Brown, M.E. (1966). Behaviour of Azotobacter chroococcum introduced into the plant Rhizosphere. Ann. Inst. Pasteur Paris. 111: 108-112.

Khan, S. and Pariari, A. (2012). Effect of $\mathrm{N}$-fixing biofertilizers on growth, yield and Quality of Chilli. The Bioscan. 7(3): 481482.

Kumar, A., A.S. and John, P.S. (1999). Integrated Nutrient Management for Sustainable Mulberry Production in Humid Tropic. In: Moriculture in Tropics Vol I. proc Natl. Sem. in Tropical Seric. UAS. GKVK, Bangalore. 53-57. 
Mallapa, B. (2015). Integrated Nutrient Management in Mulberry (Morus alba L.). M.Sc. thesis. University of Agricultural Sciences. Bangaluru.

Mallappa, B., siddappa, V.S. and Biradar, S. (2016). Effect of Integrated Nutrient Management on growth and yield of mulberry (Morus alba L.). The Bioscan. 11(2): 1303-1305.

Nakpathom, M., Somboon, B., Narumol, N. (2009). Papain enzymatic degummimg of thai Bombys mori Silk fibers, J. Microscopy Society of Thailand. 23(1): 142-146.

Nambiar, K.M. and Abrol, I.P. (1992). Long term fertilizer experiments in India-An overview. Fertilizer News. 34: 11-26.

Patel, R. and Modasiya, M. (2011). Sericin: Pharmaceutical application. International Journal of Research in Pharmaceutical and Biomedical Sciences. 2(3): 913-917.

Pilanee Vaithanomsat, Taweesiri Malapant and Waraporn Apiwattanapiwat (2008). Silk Degumming solution as substrate for microbial protease production. Kasetsart J. (Nat. Sci.) 42: 543-551.

Prashar, P. and Shah, S. (2016). Impact of Fertilizers and Pesticides on Soil Microflora in Agriculture. [E. Lichtfouse (ed.)], Sustainable Agriculture Reviews. Sustainable Agriculture Reviews 19. DOI. 10.1007/978-3-319-26777-7-8.

Pushkarnath (1976). Potato in Sub-tropics. Orient Longman. 289p.

Ram, R.L., Chatterjee, S., Maji, C., Sharma, P.K. and Singh, Y.V. (2017). Integrated effect of FYM and potassium humate on mulberry leaves and bioassay of silkworm in acid soils of Kalimpong Hills. International Journal of BioResource and Tree Management. 8(3): 405-412.

Rashmi, K., Shankar, M.A., Narayanaswamy, T.K., Sreeramulu, K.R. and Rajegowda (2006). Effect of Application of Organic Manures and Inorganic Fertilizers on Growth, Yield and Quality of S36 mulberry. National Conference on New Strategies in Research and Development of Sericulture. India Perspective, Bangalore University, Bangalore (India). pp: 36-37.

Sahay, A. and Kapila, M.L. (1993). Role of Nutrition in Synthesis of Tasar Silk. Indian Silk. 30(2): 8-11.

Sahay, A., Sahay, D.N. and Thangavelu, K. (2001). Disease management during tasar seed production. Workshop on Tasar seed production, planning and grainage. Central Tasar Research and Training Institute, Ranchi. 14-16. p: 32-45.

Sajan, K.M., Gowda, K.K., Kumar, S.N. and Sreramu, B.S. (2002). Effect of bio-fertilizers on growth and yield of chilli (Capsicum annuum L) cv. byadagi dabba at different levels of nitrogen and phosphorus. Journal of Spices and Aromatic Crops. 11(1): 58-61.
Setua, G.C., Setua, M., Ghosh, A., Debnath, S., Dutta, A.K., Benerjee, N.D. and Sarkar, A. (2007). Effect of integrated nutrient management on sustainable quality leaf production of mulberry (Morus alba) under irrigated alluvial soil conditions. Indian J. Agric. Sci. 77: 286-90.

Singh, M.K., Roy Chowdhuri, S. Naqvi, A.H., Ghosh, M.K. and Bindroo, B.B. (2012). Studies on integrated nutrient management on leaf yield and quality of silk of mulberry (Morus alba L.) grown under rainfed situation. Journal of Crop and Weed 8(2): 80-82.

Sinha, A.K., Sinha, U.S.P., Banerjee, N.P., Prasad, J. and Brahamchari, B.N. (2002). Effect of foliar spray of micronutrients on leaf yield of Terminalia arjuna and quality cocoons produced on them. Plant Archives. 2(2): 151-155.

Subsashri, M. (2004). Vermiwash an effective biopesticide. The Hindu.

Sudhakar, P., Gangawar, S.K., Satpathy, B., Sahu, P.K., Ghosh, J.K. and Saratchandra, B. (2000). Evaluation of some nitrogen fixing bacteria for control of foliar disease of mulberry (Morus alba). Indian J. Seric. 39: 9-11.

Sujathamma, P., Savithri, G., Vijaya Kumari, N., Asha Krishna, V., Vijaya, T., Sairam, K.V.S.S. and Sreerama, N., Reddy (2014). Effect of organic manures on Quantitative and Qualitative parameters of mulberry production. Hortflora Research Spectrum. 3(1): 14-20.

Suryanarayan, N., Kumar R, Gargi (2005). Monograph on Indian tropical tasar silkworm food plants (Terminalia spp.) Central Tasar Research and Training Institute. CSB, India.

Takeda, S. (2009). Sericulture. In: Encyclopedia of insects. [V. Resh and R. Carde (editors)] Academic press (chapters).

Taya, J.S., Mallik, Y.S., Pandita, M.L. and Khurana, S.C. (1994). Fertilizer management in potato based cropping system1: Growth and Yield of potato. J. Indian Potato Assoc. 21(3-4): 184-488.

Vigneswaran, C., Nivethinni, D.R., Shilpaa, K. and Dhanapal, S. (2015). Tussar Silk: Scope for Improving Quality by Enzyme Technology. JTATM. 9(3): 1-9.

Waleed, F. Hassan and Iman, Mohammad, Q. (2017). Effect of Bio-organic fertilization in some nutrients availability, Growth and yield of Cucumber (Cucumis sativus L.). IOSR Journal of Agriculture and Veterinary Science. 10(10, VerIV). pp: 13-17.

Zambare, V.P., Padul, M.V., Yadav, A.A. and Shete, T.B. (2008). Vermiwash: Biochemical and Microbiological approach as eco-friendly soil conditioner. ARPN Journal of Agricultural and Biological Science 3(4): 1-5. 